\title{
Systematic Review \\ Antimicrobial Residues in Food from Animal Origin-A Review of the Literature Focusing on Products Collected in Stores and Markets Worldwide
}

\author{
Fritz Michael Treiber * and Heide Beranek-Knauer (D) \\ Institute of Molecular Biosciences, University of Graz, Humboldtstrasse 50/EG, A-8010 Graz, Austria; \\ heide.knauer@uni-graz.at \\ * Correspondence: fritz.treiber@uni-graz.at
}

Citation: Treiber, F.M.;

Beranek-Knauer, H. Antimicrobial

Residues in Food from Animal

Origin-A Review of the Literature Focusing on Products Collected in

Stores and Markets Worldwide.

Antibiotics 2021, 10, 534. https:/ /

doi.org/10.3390/antibiotics10050534

Academic Editor: Gernot Zarfel

Received: 1 April 2021

Accepted: 30 April 2021

Published: 6 May 2021

Publisher's Note: MDPI stays neutral with regard to jurisdictional claims in published maps and institutional affiliations.

Copyright: (c) 2021 by the authors. Licensee MDPI, Basel, Switzerland. This article is an open access article distributed under the terms and conditions of the Creative Commons Attribution (CC BY) license (https:// creativecommons.org/licenses/by/ $4.0 /)$.

\begin{abstract}
The extensive use of antibiotics leads to antibiotic residues in frequently consumed foods. Generally, the main use of antibiotics in animals is to treat and prevent diseases and growth promotion. However, the residues and their breakdown products have several side effects on the human body and, in a broader sense, on the environment. In relation to the human body, the frequency of mutations is increased, the bone marrow is damaged (chloramphenicol), and the reproductive organs of humans are affected. Carcinogenic effects have been found with antibiotics such as sulfamethazine, oxytetracycline, and furazolidone. We summarized data from 73 scientific studies reporting antimicrobial residues in animal products that were freely available for sale. The studies were published in English starting from 1999 till 2021 and identified through the Pubmed search engine. The aims were to find out which antibiotics, legal or illegal, could be found in animal foods worldwide. Which are stable to get into the food chain and exceed the maximum residue limits (MRL) regarding the EU guidelines as a comparison. Reducing antimicrobial residues in food from animal origin and, in addition to this, fighting the tremendous growth and spread of antimicrobial resistance will undoubtedly be one of the most difficult food safety challenges in the coming years.
\end{abstract}

Keywords: antimicrobial residues; livestock; milk; eggs; poultry; pigs; cattle; seafood

\section{Introduction}

The discovery of antibiotics and their use in animals and humans was indisputably one of the greatest achievements of the 20th century [1]. However, the first antibiotic-resistant germs appeared as early as the 1950s [2]. With the generous use of antibiotics in animal breeding, which were also used as growth accelerators, furiously resistant germs emerged and spread [3,4]. In order to be able to cope with this problem, bans have been introduced which have banned the use of human antibiotics in animal husbandry. However, the problems with multi-resistant germs are by no means gone [5]. In some industrialized countries, there are already bans on the use of antibiotics on a preventive basis in animal breeding [6]. These may no longer be used as growth accelerators. Denmark has a prominent role in this context. In 1995, a systematic monitoring program was introduced in this country regarding the use of antibiotics in animal breeding but also in humans. It is known as DANMAP, which means Danish Integrated Antimicrobial Resistance Monitoring and Research Program [7,8]. A reduction in the use of antibiotics could be achieved with this model in Denmark [9]. Implementation of the Danish model is hardly conceivable in developing and emerging countries because there is largely a lack of laws, monitoring bodies, and structures for documentation. The great worldwide demand for animal products, also as a source of protein in the diet, often leads to the uncontrolled use of antibiotics in factory farming [10]. Meat production accounts for $73 \%$ of global antibiotic use. Forecasts on antibiotic consumption in relation to the manufacture of animal products anticipate growth of $11.5 \%$ by 2030 . The sudden accumulation of antibiotic resistance in 
livestock is especially a big challenge in developing countries. While meat consumption is falling somewhat in industrialized countries, especially in Europe, it is exploding in some developing countries. There, access to veterinary antibiotics is primarily unregulated, and the knowledge of overdosing and the development of resistance among users is deficient. It is clear that the addition of antibiotics to animal feed is the main factor behind the increased incidence and spread of antibiotic resistance [11]. Apart from this severe problem, the disposal of animal dung and the application of antibiotic-contaminated wastewater into the environment are further challenges that are often reflected in the scientific literature. In this context, antibiotic residues in foods of animal origin are also treated relatively rarely, which is another problem area. This was the decisive reason for us to make a review on this topic and the scientific articles already available on it. As for the consumption of antibiotics, the most common prescriptions for people are penicillins, macrolides, and fluoroquinolones. In contrast, tetracyclines and sulfonamides are most commonly used in animal breeding. The residues and degradation products of these substances have many undesirable side effects on the human body. It negatively influences the immune system, damages the kidneys (gentamicin), increases the frequency of mutations, can damage the liver, damages the bone marrow (chloramphenicol), and affects the human reproductive organs. Carcinogenic effects have been found with antibiotics such as sulfamethazine, oxytetracycline, and furazolidone [12]. Maximum residue limits of antibiotics regarding food help protect consumers but are no guarantees that animal products exceeding the limits will not come onto the market and be ultimately consumed by people. Even if the maximum residue limits for antibiotics in foods of animal origin are not exceeded, they can still lead to problems in the long term. For example, antibiotics used in veterinary medicine were found in food, drinking water, and urine of preschoolers in Hong Kong [13]. However, there are also special substances that need a closer look. Nitrofurazone is an antibiotic with carcinogenic properties. It can affect the DNA of cells and result in genetic toxicity that can possibly result in cancer [14]. This antibiotic has been found time and again, especially in shrimps but also in aquaculture catfish [15]. A particular challenge, in this case, is that this molecule is not so easy to detect. The right technology and the associated equipment are required so that reliable evidence can be provided [16]. Especially in underdeveloped countries regarding food safety, this is undoubtedly why nitrofurazone often goes undetected, and thus, contaminated products are also distributed on the world market and ultimately consumed.

Our review aims were as follows: (a) Which antibiotics were detected in foods of animal origin and which test methods were used? (b) How often do consumers get in contact with food contaminated with antibiotics? What country differences are there based on the published studies regarding food animal species and antimicrobial residues? (c) How often have the MRLs (EU guidelines) been exceeded in the case of positive evidence? We extracted all raw data and metrics reported in these studies, discussed the limitations of the methodologies used, and documented data gaps. We hope that this review will help regarding that. The detection of antibiotic residues in animal foods is increasingly investigated and documented, and thus, more data is made available to the scientific community.

\section{Results}

The number of first search results was huge. So, the summaries of the scientific texts had to be sorted out by hand based on the question in order to include as many papers as possible. Antibiotic residues in animal products that reached consumers had to be neatly separated from antibiotic degradation tests in tissues and methods for detecting these compounds. This resulted in the data after the first review, which was already much smaller as can be seen in Table 1. By choosing the search terms, some works were found twice. These were removed again in the last step. The 83 papers were considered as a whole and evaluated regarding eight data points. In total, 73 papers contained information regarding all eight data points. 
Table 1. Summary of the search results displayed in three steps.

\begin{tabular}{cccc}
\hline Keyword Search & Primary Search Results & Remaining after Abstract Review & $\begin{array}{c}\text { Remaining after Removal } \\
\text { of Duplicates }\end{array}$ \\
\hline Antimicrobial residues AND livestock & 381 & 16 & 8 \\
Antimicrobial residues AND seafood & 202 & 16 & 11 \\
Antimicrobial residues AND shrimp & 177 & 5 & 2 \\
Antimicrobial residues AND cattle & 1469 & 15 & 5 \\
Antimicrobial residues AND poultry & 1272 & 19 & 10 \\
Antimicrobial residues AND pork & 91 & 8 & 0 \\
Antimicrobial residues AND pig & 877 & 15 & 4 \\
Antimicrobial residues AND salmon & 95 & 5 & 0 \\
Antimicrobial residues AND milk & 1148 & 32 & 24 \\
Antimicrobial residues AND egg & 767 & 8 & 8 \\
Antimicrobial residues AND lamb & 274 & 1 & 0 \\
Antimicrobial residues AND sheep & 12 & 1 & 1 \\
\hline Total & 6765 & 141 & 73 \\
\hline
\end{tabular}

As can be seen in Figure 1, the number of publications increased steadily. Between 2016 and 2020, the number almost doubled in relation to the previously evaluated period.

\section{Published manuscripts concerning the topic 1999-2020}

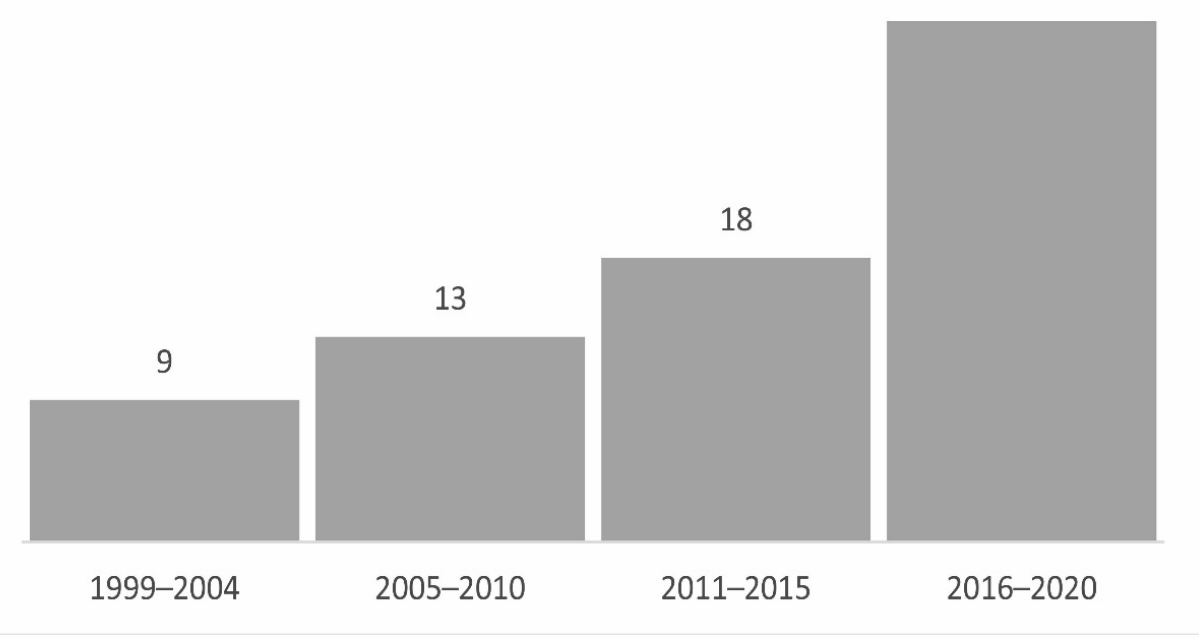

Figure 1. Evaluation of the data in relation to the publication years. For the sake of clarity, the years have been grouped into four groups.

For a clearer evaluation, all studies with salmon, other fish from aquaculture, and shrimp were combined as seafood in the evaluation, as can be seen in Figure 2. Cattle [17-22], Eggs [23-30], Milk [31-57], Pork [58-60], Poultry [58-67], Sheep [68] and seafood [58,69-83]. Combined analysis of more than one animal product was very common for pork, poultry, and seafood [63,84-92]. The data from the combined papers were divided among the individual groups of animal products. The milk from cows was an abundant source for the detection of antibiotics. This was followed by seafood, poultry, and cattle. Sheep and lamb were seldom examined. 


\section{Distribution of detected manuscripts in the literature search by product}

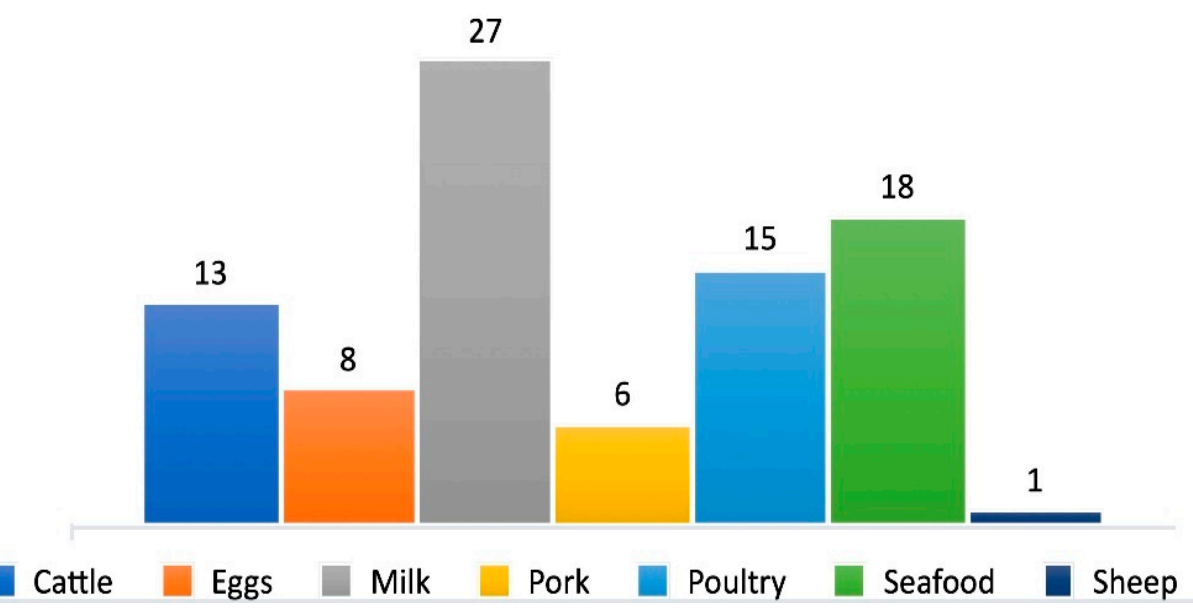

Figure 2. Distribution of manuscripts describing animal products where antibiotics still were detectable.

In Vietnam, China, and Iran, most of the studies related to antibiotic residues in animal products have been carried out, as can be seen in Figure 3. Vietnam, as well as China, produce animal products for the world market. In Iran, on the other hand, products are manufactured for the domestic market. Thailand, which, like Vietnam, produces a lot of seafood for the international market, is quite far behind in terms of the number of studies. In China, the increasingly strict legal requirements are apparently taking effect. A government program also set out to massively reduce the use of antibiotics in agriculture. However, it should be noted that the small number of studies from China regarding the number of animal products produced in that country raises further questions.

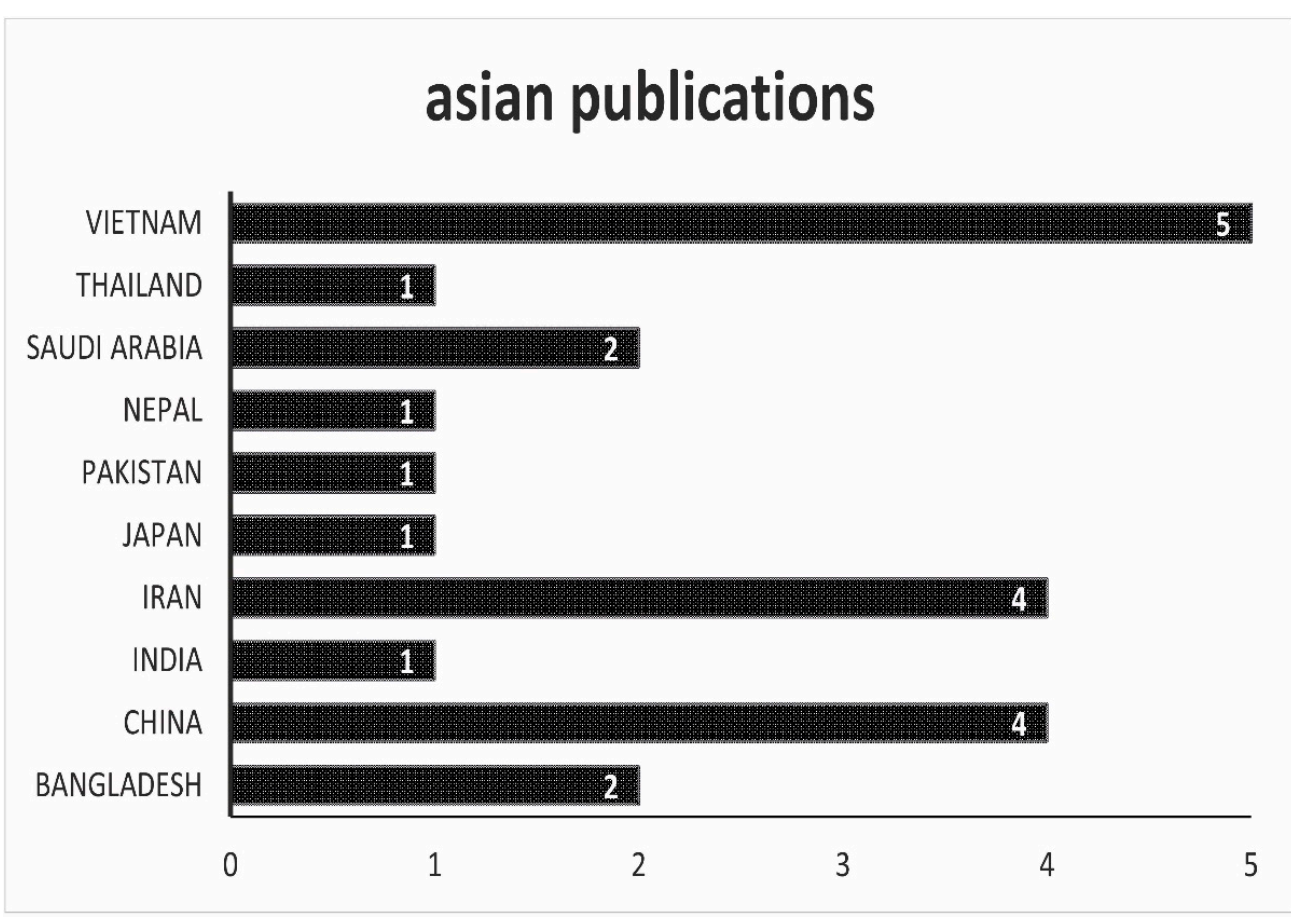

Figure 3. Overview of the origin of the scientific work. In this figure, all works that come from Asia are listed. 
Compared to Asia, the picture in Europe is entirely different, as can be seen in Figure 4. The studies are almost evenly distributed across different countries. This could be caused by the effects of the strict directives in EU policy on antibiotic residues in foods of animal origin. In many European Union countries, antibiotic residues in animal products are checked by state agencies and published nationally in annual reports.

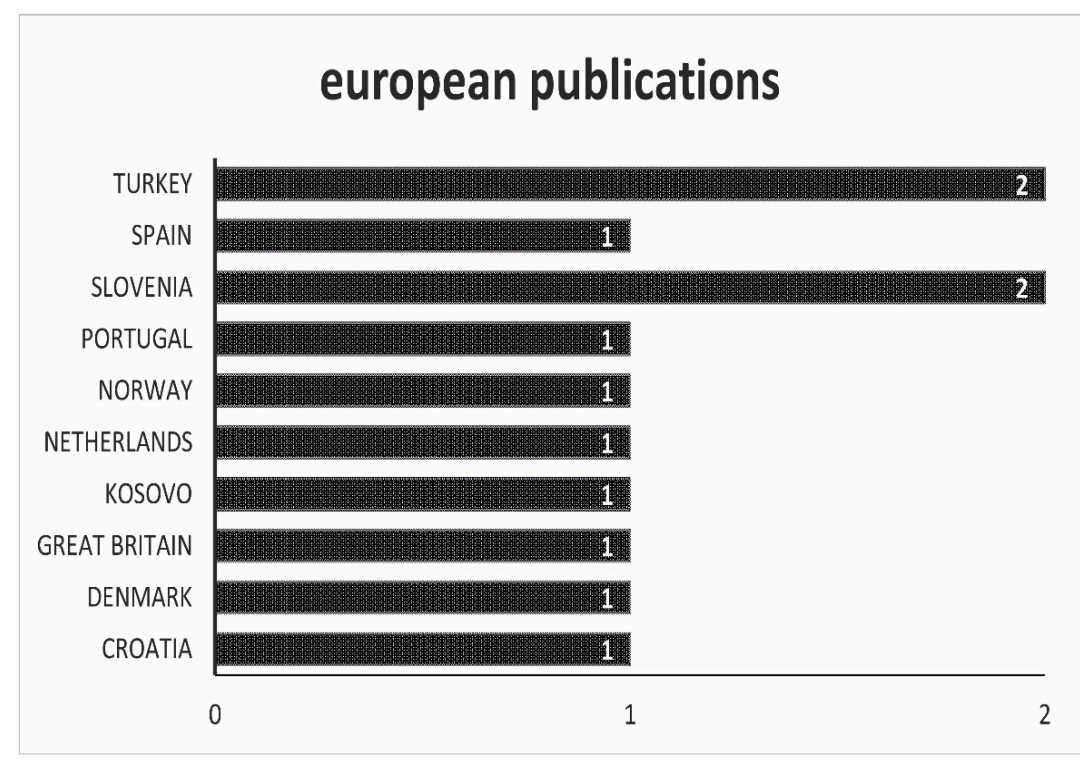

Figure 4. Overview of the origin of the scientific work. In this figure, all works that come from Europe are listed.

In the data from Africa, as can be seen in Figure 5, Nigeria stands out in particular. Much of the research on the African continent comes from the most populous country in West Africa, followed by Tanzania and other Eastern African countries. North Africa is only represented with Egypt, Algeria, and Morocco with regard to investigations into antibiotic residues. The most frequently contaminated products in this evaluation group were milk, eggs, and beef. As raw or pasteurized, milk was a rich source of antibiotic residues above and below the permitted limit values.

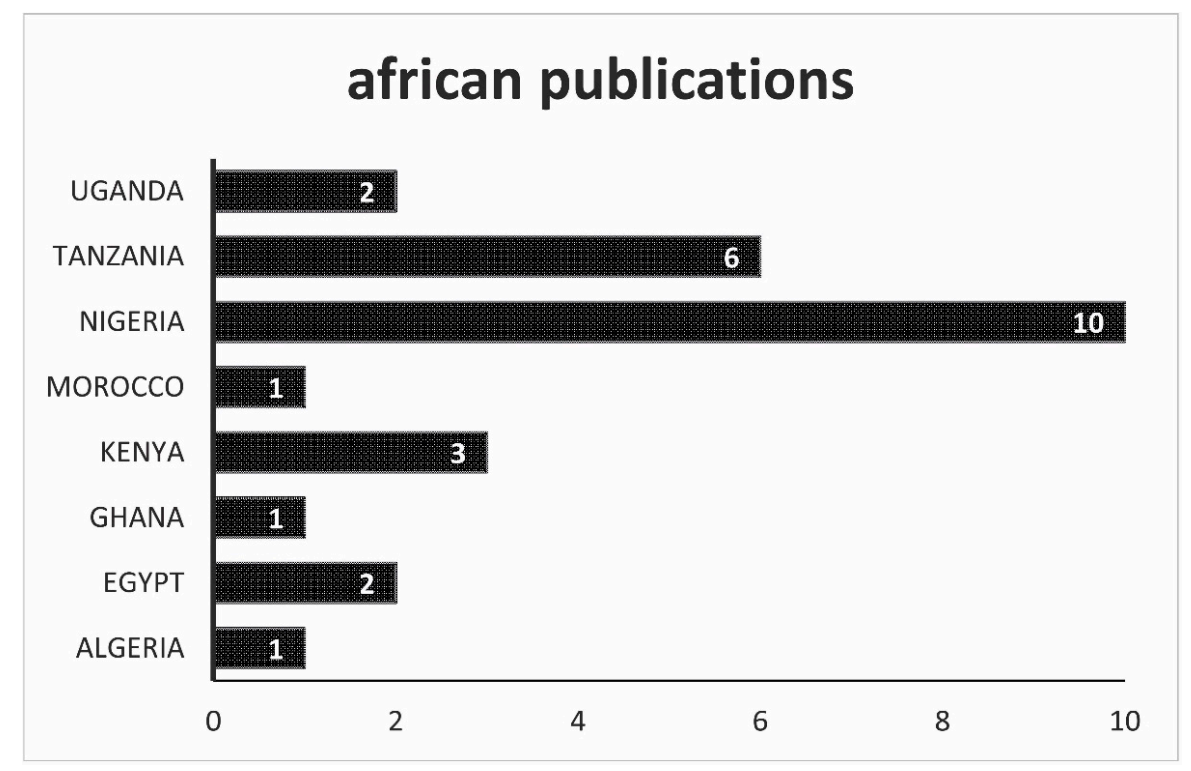

Figure 5. Overview of the origin of the scientific work. In this figure, all works that come from Africa are listed. 
The situation on the American continent is entirely different, as can be seen in Figure 6 . Here is the agar country Brazil with seven works at the top. The USA, a large agar country on this continent, has only one study may be due to a strict policy regarding the use and final concentration of antibiotics in animal products as in the EU.

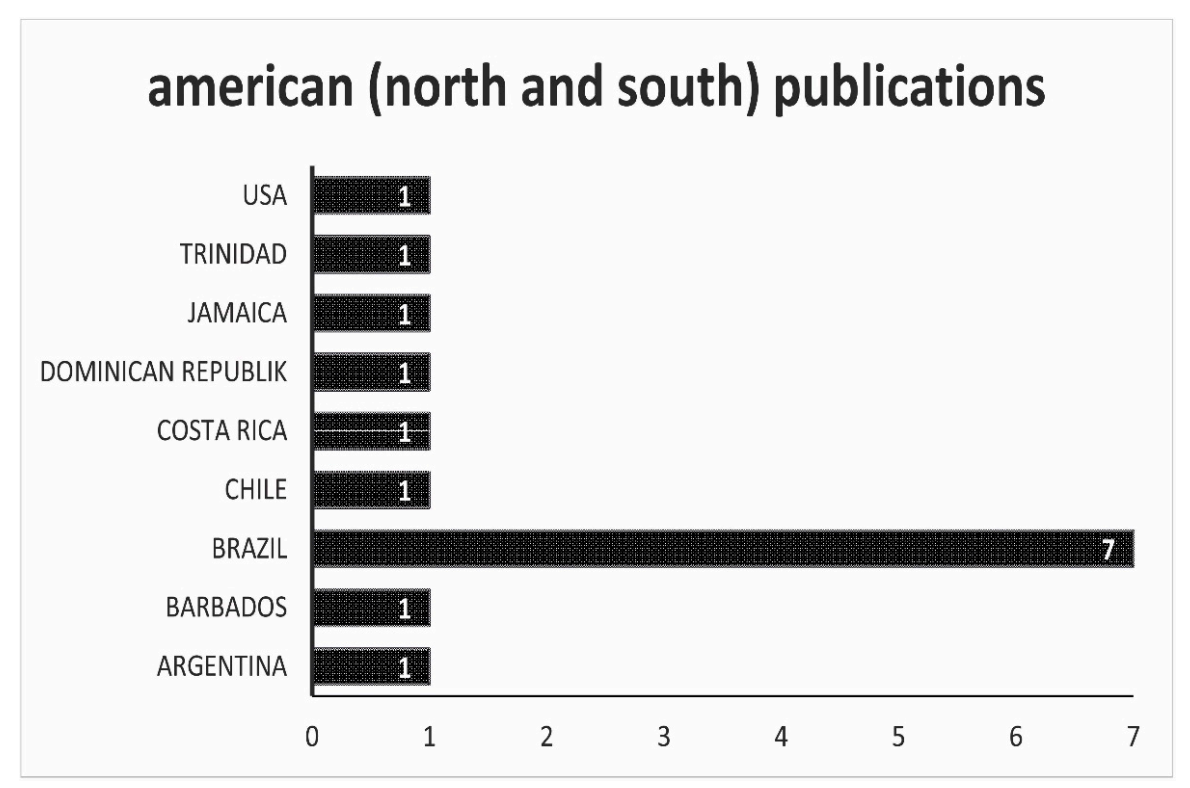

Figure 6. Overview of the origin of the scientific work. In this figure, all works that come from both American continents are listed.

The determination of antibiotic residues and the determination of their concentration in animal products were carried out in the 73 studies using different test procedures. Table 2 shows all methods of use.

Table 2. Methods and techniques used to detect various antibiotic residues in animal products.

\begin{tabular}{ccccccc}
\hline & ELISA & U/HPLC & GC & LC-MS & Inhibitor Test & Test Kits \\
\hline Cattle & 4 & 5 & 0 & 3 & 0 & 1 \\
Egg & 1 & 3 & 0 & 0 & 0 & 4 \\
Milk & 4 & 6 & 1 & 4 & 1 & 12 \\
Pork/Pig & 1 & 3 & 0 & 2 & 0 & 0 \\
Poultry & 2 & 5 & 0 & 3 & 4 & 1 \\
Seafood & 2 & 7 & 0 & 8 & 0 & 2 \\
Sheep & 0 & 0 & 0 & 0 & 0 & 1 \\
\hline Total & 14 & 29 & 1 & 20 & 5 & 21 \\
\hline
\end{tabular}

In the evaluated scientific studies, as can be seen in Table 2, the high-performance liquid chromatography (HPLC) method was used most frequently. We also added the high-performance liquid chromatography coupled with UV/VIS and UHPLC-MS/MS methods under this section. As far as laboratory analysis methods are concerned, the liquid chromatography-tandem mass spectrometry followed with some distance. Ready-made test kits were often used in order to be able to detect a range of antibiotic residues easily. The following tests were used: The Charm Blue Yellow antibiotic residue test kit (Charm Sciences Incorporated, MA, USA), Premi ${ }^{\circledR}$ test technology (R-Biopharm, Darmstadt, Germany), Copan test kit (Christian Hansen Company, Hoersholm, Denmark), Delvo SP ${ }^{\circledR}$ test kit (SP mini kit; Delft, The Netherlands), Equinox test, SNAP tetracycline test kit, SNAPbetalactam test kit, the SNAPgentamicin test kit (Idexx Laboratories, Westbrook, ME, USA), Ridascreen chloramphenicol, and streptomycin kit (R-Biopharm, Darmstadt, Germany), 
Microbial Inhibitor Tests and test kits were used, such as the microbial inhibition test using Bacillus subtilis ATCC-6633 (Thermo Fisher Diagnostics Limited, Warrington, UK).

The use of ready-made test kits was prevalent in African countries. This may also be due to the fact that other laboratory facilities were not available. In some cases, the test kits were used to detect antibiotic residues in the samples initially and then subject them to a more detailed examination method or determine the residues more precisely using this method.

Considering all 73 scientific papers evaluated, tetracycline was detected in 39 cases, as can be seen in Table 3. This antibiotic was found most often in animal products in the scientific papers that we analyzed. Most of the records came from Africa (15), followed by Asia (13), both Americas (10), and one record from Europe. The second most common antibiotic detected 22 times is oxytetracycline. Again, the most records for this substance came from Africa (10), followed by Asia (7), America (4), and Europe with one record. Penicillin $G$ was detected in 16 papers. Penicillin $G$ is known to cause allergies in some people and is, therefore, a danger in animal foods for the people concerned and should not be underestimated. The discovery of chloramphenicol, which should no longer be present in animal products, is also very worrying. This was proven in 12 studies. Regarding the records of this substance, Africa leads again with (6) cases followed by Asia (4), Europe (2), and America (0). Especially with the two works that were done in Europe, namely in Slovenia and Turkey, it is worth taking a closer look at the studies. From a total of 1308 random milk samples collected from 1991 to 2000, only one sample was contaminated with chloramphenicol at a concentration of $4.6 \mu \mathrm{g} \mathrm{kg}(-1)$ [54]. In a relatively recent study from turkey, chloramphenicol residues in sea bream (Sparus aurata) and sea bass (Dicentrarchus labrax) were found in $18.3 \%$ of the samples $(n=82)$ [69]. Scientific papers from Turkey were assigned to Europe in our evaluation. However, Turkey is not a member of the European Union and therefore also has different legislation or other directives or statutory inspection bodies regarding the use of antibiotics in agriculture. Two other substances, such as nitrofurantoin (proven in four studies) and furazolidone (proven in one study), are also on the list of prohibited substances that have no place in food.

The maximum residue limit (MRL) is the maximum allowed concentration of residue in a food product obtained from an animal that has received a veterinary medicine or that has been exposed to an antibiotic for use in animal husbandry. The substances found include a wide range of antibiotics used in agriculture. The most critical question in this context, however, is how many substances exceeded the upper limit values. This is displayed in Figure 7. In 52 cases, antibiotic residues were found that exceeded the limit values. Out of the total number of samples taken, only less than $5 \%$ of animal foods were affected.

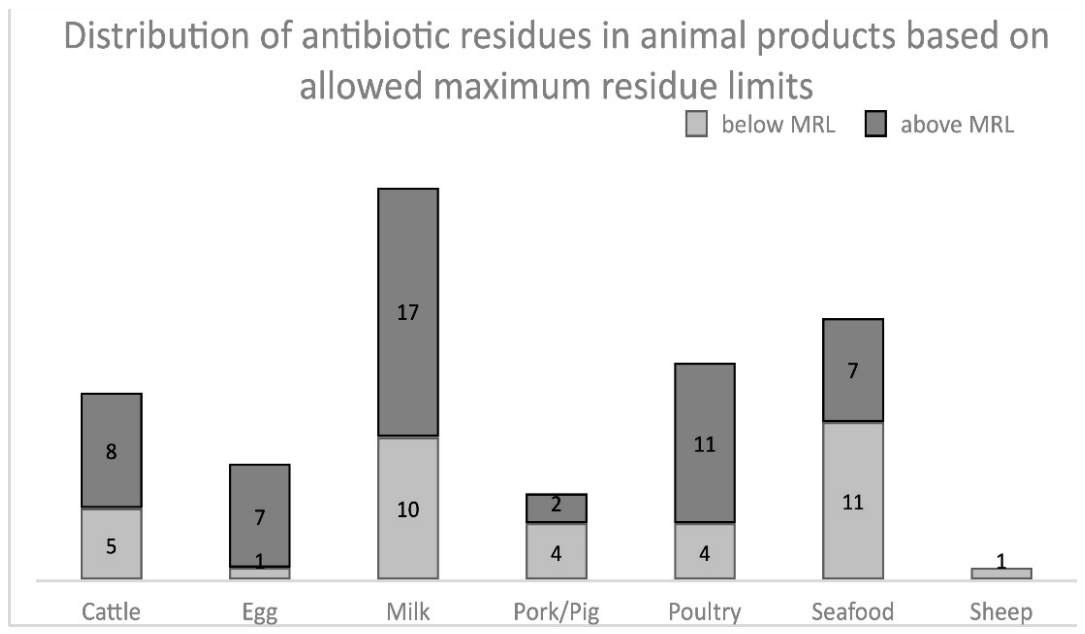

Figure 7. Distribution of antibiotic residues in animal products based on allowed maximum residue limits (MRL) regarding the 73 reviewed papers. 
Table 3. Antimicrobial residues found in different animal products.

\begin{tabular}{|c|c|c|c|c|c|c|c|c|}
\hline Antibiotic Detected & Cattle & Egg & Milk & Pork/Pig & Poultry & Seafood & Sheep & Total \\
\hline Amikacin & 0 & 0 & 0 & 1 & 0 & 0 & 0 & 1 \\
\hline Amoxicilin & 0 & 0 & 6 & 3 & 3 & 0 & 0 & 12 \\
\hline Ampicilin & 0 & 0 & 3 & 1 & 2 & 0 & 0 & 6 \\
\hline Aparamycin & 0 & 0 & 0 & 0 & 0 & 0 & 0 & 0 \\
\hline Ceftiofur & 0 & 0 & 2 & 0 & 0 & 0 & 0 & 2 \\
\hline Cephalexin & 0 & 0 & 2 & 0 & 0 & 0 & 0 & 2 \\
\hline Cephalothin & 0 & 0 & 2 & 0 & 0 & 0 & 0 & 2 \\
\hline Cephapirin & 0 & 0 & 2 & 0 & 0 & 0 & 0 & 2 \\
\hline Chloramphenicol & 0 & 4 & 4 & 1 & 0 & 3 & 0 & 12 \\
\hline Chlortetracycline & 1 & 1 & 1 & 0 & 0 & 0 & 0 & 3 \\
\hline Ciprofloxacin & 1 & 0 & 0 & 0 & 3 & 0 & 0 & 4 \\
\hline Clarithromycin & 0 & 0 & 0 & 0 & 0 & 1 & 0 & 1 \\
\hline Clindamycin & 0 & 0 & 0 & 1 & 0 & 0 & 0 & 1 \\
\hline Cloxacillin & 0 & 0 & 1 & 0 & 0 & 0 & 0 & 1 \\
\hline Doxycyclin & 0 & 1 & 0 & 1 & 1 & 1 & 0 & 4 \\
\hline Enrofloxacin & 0 & 0 & 0 & 0 & 3 & 4 & 0 & 7 \\
\hline Erythromycin & 0 & 0 & 1 & 1 & 0 & 0 & 0 & 2 \\
\hline Florfenicol & 0 & 0 & 0 & 0 & 0 & 1 & 0 & 1 \\
\hline Flumequine & 0 & 1 & 0 & 0 & 0 & 0 & 0 & 1 \\
\hline Fluoroquinolon & 1 & 0 & 0 & 1 & 2 & 2 & 0 & 6 \\
\hline Furazolidone & 0 & 0 & 0 & 0 & 0 & 1 & 0 & 1 \\
\hline Gentamycin & 0 & 0 & 4 & 1 & 1 & 1 & 0 & 7 \\
\hline Higromycin & 0 & 0 & 0 & 1 & 0 & 0 & 0 & 1 \\
\hline Kanamycin & 0 & 0 & 0 & 1 & 0 & 0 & 0 & 1 \\
\hline Lincomycin & 0 & 0 & 0 & 1 & 0 & 0 & 0 & 1 \\
\hline Neomycin & 0 & 0 & 1 & 1 & 1 & 0 & 0 & 3 \\
\hline Nitrofurantoin & 0 & 2 & 0 & 1 & 0 & 1 & 0 & 4 \\
\hline Norfloxacin & 0 & 0 & 0 & 0 & 1 & 0 & 0 & 1 \\
\hline Oxytetracycline & 5 & 3 & 5 & 1 & 5 & 3 & 0 & 22 \\
\hline Penicilin G & 7 & 0 & 9 & 0 & 0 & 0 & 0 & 16 \\
\hline Quinolone & 1 & 1 & 1 & 0 & 2 & 0 & 0 & 5 \\
\hline Roxithromycin & 0 & 0 & 0 & 0 & 0 & 1 & 0 & 1 \\
\hline Streptomycin & 1 & 0 & 3 & 1 & 1 & 0 & 0 & 6 \\
\hline Sulfanilamide & 0 & 1 & 0 & 0 & 0 & 0 & 0 & 1 \\
\hline Sulfadiazine & 1 & 1 & 3 & 3 & 0 & 2 & 0 & 10 \\
\hline Sulfaguanidine & 0 & 0 & 0 & 0 & 0 & 1 & 0 & 1 \\
\hline Sulfamethazine & 1 & 1 & 2 & 1 & 4 & 1 & 0 & 10 \\
\hline Sulfisoxazole & 0 & 0 & 1 & 0 & 0 & 0 & 0 & 1 \\
\hline Sulfmethoxazole & 1 & 0 & 0 & 0 & 0 & 4 & 0 & 5 \\
\hline Sulfmethoxydiazine & 1 & 1 & 2 & 0 & 0 & 2 & 0 & 6 \\
\hline Sulfmethoxypyridazine & 0 & 1 & 1 & 0 & 0 & 0 & 0 & 2 \\
\hline Sulfaquinoxaline & 1 & 0 & 0 & 0 & 2 & 0 & 0 & 3 \\
\hline Sulphanilamide & 0 & 0 & 0 & 0 & 0 & 0 & 0 & 0 \\
\hline Tetracycline & 8 & 3 & 13 & 3 & 8 & 3 & 1 & 39 \\
\hline Thiamphenicol & 0 & 0 & 0 & 0 & 0 & 1 & 0 & 1 \\
\hline Tobramycin & 0 & 0 & 0 & 1 & 0 & 0 & 0 & 1 \\
\hline Trimethoprim & 0 & 0 & 0 & 0 & 1 & 2 & 0 & 3 \\
\hline Trimetoprim & 0 & 0 & 0 & 0 & 0 & 0 & 0 & 0 \\
\hline Tylmicosin & 0 & 0 & 0 & 1 & 0 & 0 & 0 & 1 \\
\hline
\end{tabular}

\section{Discussion}

In this work, we reviewed 73 studies on antimicrobial residues in animal products published in English since 1999. In relation to the importance of this topic, the number of publications found was relatively small. This finding can have several causes. In the USA, the European Union, and some Asian countries, the legal guidelines regarding antibiotic residues in food are relatively strict and are also checked by state authorities. A scientific study by non-governmental research groups, therefore, does not seem worthwhile. 
Unfortunately, there are often rumors among the population in industrialized countries that the foods available there are full of antibiotics, pesticides, and hormones, which would cause serious health problems. It must be noted here that it is precisely in these countries that food safety is highest in terms of residues of various chemicals and pathogenic germs or parasites. Many European countries have already banned the addition of antibiotics to animal feed as a preventive measure in relation to the avoidance of diseases in livestock farms $[6,93]$. Additionally, the European Union has introduced the maximum limit values for residues of various substances in milk. However, it must be said here that such limit values do not guarantee the absence of drug residues in milk or dairy products. In addition, the study situation is deplorable if one looks at the spread of antibiotic residues from milk in processed dairy products. How high the number of residues is and how they affect the human body has hardly been researched [94]. The situation is different in many emerging and developing countries in Asia, Africa, and South America. Many factors promote the presence of antibiotic residues in meat products, especially in developing countries. The main reasons are as follows: (1) The time each antibiotic needs to be broken down or excreted in the animal organism often lacks for both breeders and butchers; (2) there is no complete monitoring from the prescription to the use of the substances; (3) the detection methods are often inadequate or not available at all, in order to comply with limit values; and (4) the absence of certification systems regarding food products from animal origin. A wide range of antibiotics has been found in the following products: milk, eggs, poultry, beef, pork, seafood, fish, and mutton. Particular attention should be paid to antibiotics that are toxic to humans even in low concentrations, such as chloramphenicol and tetracycline. Various studies have shown that antibiotic residues from food can negatively impact human health in the form of allergic reactions, mutations in cells, the development of imbalances in the intestinal microbiome, and, ultimately, multi-resistant germs. In addition to this, rapid tests, which include many of the antibiotics used in animal breeding, have been the only means of analysis in some countries. Such evidence is somewhat vague but at least allows conclusions to be drawn as to which antibiotics can be found in food or are increasingly used on farms. The same applies to the few papers that used microbiological assays.

Products that exceed the maximum allowed residue limits pose a serious problem. Heat treatments that occur in cooking processes can reduce the risk of ingestion of sulfonamides, tetracyclines $[95,96]$, and fluoroquinolones but do not guarantee their breakdown or the complete breakdown of these antibiotics' residues in animal products, such as broiler meat. The high stability of quinolones [97] and $\beta$-lactams [98] represents a significant risk to human health because the residues of these antibiotics can remain in milk after heat treatment and, therefore, can reach the dairy industry and consumers. Regarding white shrimp (Penaeus indicus) that contained chloramphenicol residues, this drug gets destroyed or degraded during heat processing treatments [99]. Furthermore, the toxic effects of the degradation products will also have to be examined more closely in the future. Their formation in cooked meat should definitely be included in the maximum limits for antibiotic residues when these are set.

Apart from that, concentrations of antibiotic residues vary between different edible muscle tissues [100]. However, in the case of muscle tissue, the regulatory process does not differentiate between different edible muscle types in poultry. Previous studies showed that higher fluoroquinolone residue concentrations in breast versus thigh muscle [101].

The previous findings of this work were able to locate most of the problems with antibiotic residues in developing countries and emerging economies. It must not be forgotten that due to world trade, many of these animal products also end up on the plates of western consumers. Seafood and fish from aquaculture should be mentioned here. Due to the many positive properties in relation to a balanced diet, the consumption of these animal products is also increasing sharply $[102,103]$. This means that antibiotic residues are also imported, and incorrect information on origin is an increasing problem. Monitoring these imports as completely as possible would also be advisable in western countries [71]. Efficient detection methods are also available in these countries. 
In many European countries, as well as in the USA, there is a trend in animal breeding and husbandry to keep them in their natural habitat, away from factory farming in large stables. In addition, consumers want more and more meat from animals that have been treated with as few antibiotics as possible during rearing and until slaughter. However, can this desire of consumers be implemented without any problems? In a Danish study regarding consumer preferences for meat with reduced antibiotic use in pig production, two-thirds of the consumers stated a positive will to pay more for this product. However, only one in five were willing to pay more than $10 \%$ for pork produced using antibiotics, $20 \%$ less than average [104]. While consumers are increasingly demanding pork products that have been reared without antibiotics, bacteria and parasites multiply precisely among these pigs, which are subsequently associated with human diseases that are ingested through food or arise through this route. A comparative study on pigs that were freely bred with antibiotics and others that came from conventional breeding showed clear results. The pigs that were bred outdoors under natural conditions had noticeably higher rates of questionable germs than the pigs from conventional breeding. The incidence of Salmonella was significantly higher in the antibiotic-free-bred herds than in the control herd. Therefore, it is questionable to what extent pigs that have been bred freely with antibiotics are considered safe food [105].

The presence of antibiotic residues in meat products that are above the maximum permitted limits is a serious problem. Based on the values of the maximum levels of residues in animal tissue and in relation to the daily consumption calculated on the bodyweight of the person, these residues should not pose a health risk. Exceptions are allergic reactions to antibiotics. In this context, however, a possible connection must be mentioned.

There appears to be a relationship between antibiotic use and the increase in obesity in people. The number of publications on this topic is increasing steadily. Some authors point out that there is a direct link between the increased use of antibiotics in animal breeding and the increase in the number of obese people in our society over the past 70 years [106]. It would be possible that the long-term and low-dose intake of antibiotic residues via animal food products has permanently disrupted the balance of the microbiome in the intestine, which was subsequently jointly responsible for the weight gain $[107,108]$. The intestinal microbiome has many tasks that only became known or could be researched in more detail in the last 15 years. The microorganisms help with the digestion of food and with the release of various nutrients, keep various pathogenic germs in check, stimulate or modulate the immune system and have tasks in communication regarding the intestinal-brain axis [109]. Furthermore, there are indications that an imbalance in the intestinal microbiome at a young age can lead to numerous metabolic disorders in later years of life. These include diabetes, various allergies or intolerances, obesity, complaints in the cardiovascular system, and neurological problems.

\section{Materials and Methods}

\subsection{Scientific Paper Selection}

The PubMed engine (National Library of Medicine-8600 Rockville Pike Bethesda, MD 20894 https://pubmed.ncbi.nlm.nih.gov/, the website was accessed on 15 March 2021) was used to search for original scientific papers published in English from January 1999 to March 2021. The following terms were used to search scientific papers using the following keywords: (antimicrobial* OR antibiotic ${ }^{*}$ AND (cattle* OR lamb* OR sheep* OR poultry* OR egg* OR pork* OR pig* OR livestock* OR shrimp* OR salmon* OR milk* OR seafood $^{*}$ ). All retrieved records were saved for further review. Publications not reporting original research data or written in languages other than English were further excluded. Publications containing antimicrobial residues data in the abstract were selected for a first investigation. All scientific papers that dealt with residues of antibiotics were excluded, but in the sense of detection methods or residues in the environment, as well as pollution of animal manure, the rest that contained only research data regarding antimicrobial residues in animal food were reviewed with full content. In addition to the techniques used to 
detect antibiotic residues, the size of the sample was also an important quality criterion for us. We divided the sample sizes into 6 categories. Up to 50 samples were documented in 16 publications. Up to 100 samples were documented in 19 papers. Up to 200 samples were documented in 20 papers. Up to 300 samples were documented in 12 papers. Up to 400 papers were documented in 6 papers. Twelve papers were summarized for a sample size of over 400 up to 25,000 . All work with a sample number below 50 was subjected to a thorough analysis regarding sampling and analytical methods. If this was correct or meaningful, this data was included in our evaluation. Publications were broadly classified by the country where the research took place, year of publishing, and further categorization regarding the animal food product.

\subsection{Data Extraction}

From each selected publication, the following information was compiled as separate records (data points): (1) country of study, (2) year, (3) type of animal product, (4) sample size, (5) animal production type, (6) antibiotics found, (7) detection method, and (8) over maximum residue limits.

All data were entered as single records ('datapoints') in Excel (Microsoft Office). Antimicrobials and antimicrobial classes listed were those included in the World Organisation for Animal Health (OIE) classification: veterinary critically important antimicrobial (VCIA) agents (10 classes); veterinary highly important antimicrobial (VHIA) agents (8 classes); and important veterinary antimicrobial (VIA) agents (8 classes) [17].

\section{Conclusions}

The problem of antimicrobial residues in animal products is not new. However, due to the globalization of the food trade, we are constantly facing new challenges. Reduction of the antimicrobial volumes currently used by humans and livestock and limiting the use of broad-spectrum and critically important antimicrobials would be essential. Educational work regarding antimicrobial residues in animal products and the associated development of multi-resistant germs must be stepped up in developing countries. This can only be reduced through increased monitoring of the use of antibiotics in animal breeding. In any case, users must be informed about the health consequences for their customers regarding antibiotic residues in animal products and the development of multi-resistant germs. The ban on the disposal of rubbish, sewage, and manure containing antibiotics must also be mentioned in this context. Alternatives to antibiotics, such as various vaccinations, the use of phages, and phage therapy, must be promoted. The use of prebiotics and probiotics in animal feed and the use of traditional medicinal herbs must also be further researched to ultimately reduce the use of antibiotics in animal breeding to a realistic amount.

Author Contributions: Both authors contributed equally to this work. All authors have read and agreed to the published version of the manuscript.

Funding: This research received no external funding.

Acknowledgments: Open Access Funding by the University of Graz. In addition to this we thank the team of the seventh faculty of the University of Graz and, especially, Helmut Jungwirth for supporting our work and ideas.

Conflicts of Interest: The authors declare no conflict of interest.

\section{References}

1. Page, S.; Gautier, P. Use of antimicrobial agents in livestock. Rev. Sci. Tech. 2012, 31, 145-188. [CrossRef]

2. Bell, B.G.; Schellevis, F.; Stobberingh, E.; Goossens, H.; Pringle, M. A systematic review and meta-analysis of the effects of antibiotic consumption on antibiotic resistance. BMC Infect. Dis. 2014, 14, 13. [CrossRef] [PubMed]

3. Simoneit, C.; Burow, E.; Tenhagen, B.-A.; Käsbohrer, A. Oral administration of antimicrobials increase antimicrobial resistance in E. coli from chicken-A systematic review. Prev. Vet. Med. 2015, 118, 1-7. [CrossRef]

4. Chantziaras, I.; Boyen, F.; Callens, B.; Dewulf, J. Correlation between veterinary antimicrobial use and antimicrobial resistance in food-producing animals: A report on seven countries. J. Antimicrob. Chemother. 2014, 69, 827-834. [CrossRef] [PubMed] 
5. World Health Organization. The Evolving Threat of Antimicrobial Resistance: Options for Action; World Health Organization: Geneva, Switzerland, 2012.

6. Muaz, K.; Riaz, M.; Akhtar, S.; Park, S.; Ismail, A. Antibiotic Residues in Chicken Meat: Global Prevalence, Threats, and Decontamination Strategies: A Review. J. Food Prot. 2018, 81, 619-627. [CrossRef]

7. Bager, F. DANMAP: Monitoring antimicrobial resistance in Denmark. Int. J. Antimicrob. Agents 2000, 14, 271-274. [CrossRef]

8. World Health Organization. Resistance monitoring in Denmark, 1997-DANMAP. Wkly. Epidemiol. Rec. 1999, 74, $125-127$.

9. Levy, S. Reduced Antibiotic Use in Livestock: How Denmark TackledResistance. Environ. Health Perspect. 2014, 122, A160-A165. [CrossRef]

10. Van Boeckel, T.P.; Brower, C.C.; Gilbert, M.; Grenfell, B.T.; Levin, S.A.S.; Robinson, T.P.; Teillant, A.A.; Laxminarayan, R.R. Global trends in antimicrobial use in food animals. Proc. Natl. Acad. Sci. USA 2015, 112, 5649-5654. [CrossRef]

11. Tiseo, K.; Huber, L.; Gilbert, M.; Robinson, T.P.; Van Boeckel, T.P. Global Trends in Antimicrobial Use in Food Animals from 2017 to 2030. Antibiotics 2020, 9, 918. [CrossRef]

12. Bacanll, M.; Başaran, N. Importance of antibiotic residues in animal food. Food Chem. Toxicol. 2019, 125, 462-466. [CrossRef]

13. Li, N.; Ho, K.W.; Ying, G.-G.; Deng, W.-J. Veterinary antibiotics in food, drinking water, and the urine of preschool children in Hong Kong. Environ. Int. 2017, 108, 246-252. [CrossRef]

14. Hiraku, Y.; Sekine, A.; Nabeshi, H.; Midorikawa, K.; Murata, M.; Kumagai, Y.; Kawanishi, S. Mechanism of carcinogenesis induced by a veterinary antimicrobial drug, nitrofurazone, via oxidative DNA damage and cell proliferation. Cancer Lett. 2004, 215, 141-150. [CrossRef]

15. Wang, Y.; Jester, E.L.E.; El Said, K.R.; Abraham, A.; Hooe-Rollman, J.; Plakas, S.M. Cyano Metabolite as a Biomarker of Nitrofurazone in Channel Catfish. J. Agric. Food Chem. 2010, 58, 313-316. [CrossRef]

16. Wang, Q.; Wang, X.-F.; Jiang, Y.-Y.; Li, Z.-G.; Cai, N.; Guan, W.-Q.; Huang, K.; Zhao, D.-H. Determination of 5-nitro-2-furaldehyde as marker residue for nitrofurazone treatment in farmed shrimps and with addressing the use of a novel internal standard. Sci. Rep. 2019, 9, 19243. [CrossRef]

17. Omeiza, G.K.; Ajayi, I.E.; Ode, O.J. Assessment of antimicrobial drug residues in beef in Abuja, the Federal Capital Territory, Nigeria. Vet. Ital. 2012, 48, 283-289.

18. Adesokan, H.K.; Agada, C.A.; Adetunji, V.O.; Akanbi, I.M. Oxytetracycline and penicillin-G residues in cattle slaughtered in south-western Nigeria: Implications for livestock disease management and public health. J. S. Afr. Vet. Assoc. 2013, 84, 5. [CrossRef]

19. Muriuki, F.K.; Ogara, W.O.; Njeruh, F.M.; Mitema, E.S. Tetracycline residue levels in cattle meat from Nairobi salughter house in Kenya. J. Vet. Sci. 2001, 2, 97-101. [CrossRef] [PubMed]

20. Basulira, Y.; Olet, S.A.; Alele, P.E. Inappropriate usage of selected antimicrobials: Comparative residue proportions in rural and urban beef in Uganda. PLoS ONE 2019, 14, e0209006. [CrossRef] [PubMed]

21. Kimera, Z.I.; Mdegela, R.H.; Mhaiki, C.J.; Karimuribo, E.D.; Mabiki, F.; Nonga, H.E.; Mwesongo, J. Determination of oxytetracycline residues in cattle meat marketed in the Kilosa district, Tanzania. Onderstepoort J. Vet. Res. 2015, 82, 5. [CrossRef] [PubMed]

22. Morshdy, A.E.M.A.; El-Atabany, A.I.; Hussein, M.A.M.; Darwish, W.S. Oxytetracycline residues in bovine carcasses slaughtered at Mansoura Abattoir, Egypt. Jpn. J. Vet. Res. 2013, 61, 44-47.

23. Nonga, H.E.; Simon, C.; Karimuribo, E.D.; Mdegela, R.H. Assessment of Antimicrobial Usage and Residues in Commercial Chicken Eggs from Smallholder Poultry Keepers in Morogoro Municipality, Tanzania. Zoonoses Public Health 2009, 57, 339-344. [CrossRef] [PubMed]

24. Ezenduka, E.V.; Oboegbulem, S.I.; Nwanta, J.A.; Onunkwo, J.I. Prevalence of antimicrobial residues in raw table eggs from farms and retail outlets in Enugu State, Nigeria. Trop. Anim. Health Prod. 2010, 43, 557-559. [CrossRef]

25. Adesiyun, A.; Offiah, N.; Lashley, V.; Seepersadsingh, N.; Rodrigo, S.; Georges, K. Prevalence of Antimicrobial Residues in Table Eggs in Trinidad. J. Food Prot. 2005, 68, 1501-1505. [CrossRef] [PubMed]

26. Moscoso, S.; Santos, F.S.D.L.; Andino, A.G.; Díaz-Sánchez, S.; Hanning, I. Detection of Quinolones in Commercial Eggs Obtained from Farms in the Espaíllat Province in the Dominican Republic. J. Food Prot. 2015, 78, 214-217. [CrossRef]

27. Omeiza, G.K.; Kabir, J.; Mamman, M.; Ibrahim, H.; Fagbamila, I.O. Response of Nigerian farmers to a questionnaire on chloramphenicol application in commercial layers. Vet. Ital. 2012, 48, 87-93.

28. Olatoye, O.; Kayode, S.T. Oxytetracycline residues in retail chicken eggs in Ibadan, Nigeria. Food Addit. Contam. Part B 2012, 5, 255-259. [CrossRef]

29. Mbodi, F.E.; Nguku, P.; Okolocha, E.; Kabir, J. Determination of chloramphenicol residues in commercial chicken eggs in the Federal Capital Territory, Abuja, Nigeria. Food Addit. Contam. Part A 2014, 31, 1834-1839. [CrossRef]

30. Al-Ghamdi, M. Residues of tetracycline compounds in poultry products in the eastern province of Saudi Arabia. Public Health 2000, 114, 300-304. [CrossRef]

31. Redding, L.; Cubas-Delgado, F.; Sammel, M.; Smith, G.; Galligan, D.; Levy, M.; Hennessy, S. Antibiotic residues in milk from small dairy farms in rural Peru. Food Addit. Contam. Part A 2014, 31, 1001-1008. [CrossRef]

32. Gwandu, S.H.; Nonga, H.E.; Mdegela, R.H.; Katakweba, A.S.; Suleiman, T.S.; Ryoba, R. Assessment of Raw Cow Milk Quality in Smallholder Dairy Farms in Pemba Island Zanzibar, Tanzania. Vet. Med. Int. 2018, 2018, 1031726. [CrossRef]

33. Moghadam, M.M.; Amiri, M.; Riabi, H.R.A.; Riabi, H.R.A. Evaluation of Antibiotic Residues in Pasteurized and Raw Milk Distributed in the South of Khorasan-e Razavi Province, Iran. J. Clin. Diagn. Res. 2016, 10, FC31-FC35. [CrossRef] 
34. Tempini, P.; Aly, S.; Karle, B.; Pereira, R. Multidrug residues and antimicrobial resistance patterns in waste milk from dairy farms in Central California. J. Dairy Sci. 2018, 101, 8110-8122. [CrossRef]

35. Siljanoski, A.; Ciglarič, R.; Pezdir, T.; Lainšček, P.R.; Dolenc, J.; Starič, J.; Šinigoj-Gačnik, K. Detection of tetracycline and other antimicrobial residues in milk from cows with clinical mastitis treated by combination therapy. J. Dairy Res. 2018, 85, 321-326. [CrossRef]

36. Bando, E.; Oliveira, R.C.; Ferreira, G.M.Z.; Machinski, M. Occurrence of Antimicrobial Residues in Pasteurized Milk Commercialized in the State of Paraná, Brazil. J. Food Prot. 2009, 72, 911-914. [CrossRef]

37. Brown, K.; Mugoh, M.; Call, D.R.; Omulo, S. Antibiotic residues and antibiotic-resistant bacteria detected in milk marketed for human consumption in Kibera, Nairobi. PLoS ONE 2020, 15, e0233413. [CrossRef] [PubMed]

38. Kosgey, A.; Shitandi, A.; Marion, J.W. Antibiotic Residues in Milk from Three Popular Kenyan Milk Vending Machines. Am. J. Trop. Med. Hyg. 2018, 98, 1520-1522. [CrossRef] [PubMed]

39. Rama, A.; Lucatello, L.; Benetti, C.; Galina, G.; Bajraktari, D. Assessment of antibacterial drug residues in milk for consumption in Kosovo. J. Food Drug Anal. 2017, 25, 525-532. [CrossRef] [PubMed]

40. Khanal, B.K.S.; Sadiq, M.B.; Singh, M.; Anal, A.K. Screening of antibiotic residues in fresh milk of Kathmandu Valley, Nepal. J. Environ. Sci. Health Part B 2017, 53, 57-86. [CrossRef]

41. Baazize-Ammi, D.; Dechicha, A.S.; Tassist, A.; Gharbi, I.; Hezil, N.; Kebbal, S.; Morsli, W.; Beldjoudi, S.; Saadaoui, M.R.; Guetarni, D. Screening and quantification of antibiotic residues in broiler chicken meat and milk in the central region of Algeria. Rev. Sci. Tech. 2019, 38, 863-877. [CrossRef] [PubMed]

42. Shi, R.; Yu, Z.; Wu, W.; Ho, H.; Wang, J.; Wang, Y.; Han, R. A Survey of 61 Veterinary Drug Residues in Commercial Liquid Milk Products in China. J. Food Prot. 2020, 83, 1227-1233. [CrossRef]

43. Shitandi, A.; Sternesjö, Å. Factors Contributing to the Occurrence of Antimicrobial Drug Residues in Kenyan Milk. J. Food Prot. 2004, 67, 399-402. [CrossRef]

44. Addo, K.K.; Mensah, G.I.; Aning, K.G.; Nartey, N.; Nipah, G.K.; Bonsu, C.; Akyeh, M.L.; Smits, H.L. Microbiological quality and antibiotic residues in informally marketed raw cow milk within the coastal savannah zone of Ghana. Trop. Med. Int. Health 2010, 16, 227-232. [CrossRef]

45. Baynes, R.E.; Lyman, R.; Anderson, K.L.; Brownie, C.F. A Preliminary Survey of Antibiotic Residues and Viable Bacteria in Milk from Three Caribbean Basin Countries. J. Food Prot. 1999, 62, 177-180. [CrossRef]

46. Vragović, N.; Bažulić, D.; Njari, B. Risk assessment of streptomycin and tetracycline residues in meat and milk on Croatian market. Food Chem. Toxicol. 2011, 49, 352-355. [CrossRef] [PubMed]

47. De Oliveira, R.C.; Paschoal, J.A.; Reyes, F.G. Streptomycin and dihydrostreptomycin residues in bovine milk from the Brazilian retail market. Food Addit. Contam. Part B 2010, 3, 156-162. [CrossRef] [PubMed]

48. Mdegela, R.; Ryoba, R.; Karimuribo, E.; Phiri, E.; Loken, T.; Reksen, O.; Mtengeti, E.; Urio, N. Prevalence of clinical and subclinical mastitis and quality of milk on smallholder dairy farms in Tanzania. J. S. Afr. Vet. Assoc. 2009, 80, 163-168. [CrossRef] [PubMed]

49. Prado, C.K.; Ferreira, F.D.; Bando, É.; Machinski, M. Oxytetracycline, tetracycline, chlortetracycline and doxycycline in pasteurised cow's milk commercialised in Brazil. Food Addit. Contam. Part B 2015, 8, 81-84. [CrossRef]

50. Yamaki, M.; Berruga, M.; Althaus, R.; Molina, M.; Molina, A. Occurrence of Antibiotic Residues in Milk from Manchega Ewe Dairy Farms. J. Dairy Sci. 2004, 87, 3132-3137. [CrossRef]

51. Zheng, N.; Wang, J.; Han, R.; Xu, X.; Zhen, Y.; Qu, X.; Sun, P.; Li, S.; Yu, Z. Occurrence of several main antibiotic residues in raw milk in 10 provinces of China. Food Addit. Contam. Part B 2013, 6, 84-89. [CrossRef]

52. Fernandes, S.A.D.A.; Magnavita, A.P.A.; Ferrão, S.P.B.; Gualberto, S.A.; Faleiro, A.S.; Figueiredo, A.J.; Matarazzo, S.V. Daily ingestion of tetracycline residue present in pasteurized milk: A public health problem. Environ. Sci. Pollut. Res. 2013, 21, 3427-3434. [CrossRef]

53. Mohamadi Sani A-Search Results-PubMed, (n.d.). Available online: https:/ / pubmed.ncbi.nlm.nih.gov/?term=mohamadi+ sani+a (accessed on 23 April 2021).

54. Cerkvenik, V. Analysis and monitoring of chloramphenicol residues in food of animal origin in Slovenia from 1991 to 2000 . Food Addit. Contam. 2002, 19, 357-367. [CrossRef]

55. Kurwijila, L.R.; Omore, A.; Staal, S.; Mdoe, N.S.Y. Investigation of the Risk of Exposure to Antimicrobial Residues Present in Marketed Milk in Tanzania. J. Food Prot. 2006, 69, 2487-2492. [CrossRef]

56. Zanella, G.N.; Mikcha, J.M.G.; Bando, E.; Siqueira, V.L.D.; Machinski, M. Occurrence and Antibiotic Resistance of Coliform Bacteria and Antimicrobial Residues in Pasteurized Cow's Milk from Brazil. J. Food Prot. 2010, 73, 1684-1687. [CrossRef]

57. Kivaria, F.M.; Noordhuizen, J.P.T.M.; Kapaga, A.M. Evaluation of the hygienic quality and associated public health hazards of raw milk marketed by smallholder dairy producers in the Dar es Salaam region, Tanzania. Trop. Anim. Health Prod. 2006, 38, 185-194. [CrossRef]

58. Olusola, A.V.; Diana, B.E.; Ayoade, O.I. Assessment of Tetracycline, Lead and Cadmium Residues in Frozen Chicken Vended in Lagos and Ibadan, Nigeria. Pak. J. Biol. Sci. 2012, 15, 839-844. [CrossRef] [PubMed]

59. Er, B.; Onurdağ, F.K.; Demirhan, B.; Özgacar, S.Ö.; Öktem, A.B.; Abbasoğlu, U. Screening of quinolone antibiotic residues in chicken meat and beef sold in the markets of Ankara, Turkey. Poult. Sci. 2013, 92, 2212-2215. [CrossRef]

60. Al-Mustafa, Z.H.; Al-Ghamdi, M.S. Use of norfloxacin in poultry production in the eastern province of Saudi Arabia and its possible impact on public health. Int. J. Environ. Health Res. 2000, 10, 291-299. [CrossRef] [PubMed] 
61. Ezenduka, E.V. Screening of antimicrobial residues in poultry meat in Enugu metropolis, Enugu State, South East Nigeria. Vet. Ital. 2019, 55, 143-148.

62. Ferdous, J.; Bradshaw, A.; Islam, S.K.M.A.; Zamil, S.; Islam, A.; Ahad, A.; Fournie, G.; Anwer, M.S.; Hoque, A. Antimicrobial Residues in Chicken and Fish, Chittagong, Bangladesh. EcoHealth 2019, 16, 429-440. [CrossRef] [PubMed]

63. Huong, L.Q.; Hang, T.T.T.; Ngoc, P.T.; Van Tuat, C.; Erickson, V.I.; Padungtod, P. Pilot Monitoring of Antimicrobial Residues in Chicken and Pork in Vietnam. J. Food Prot. 2020, 83, 1701-1706. [CrossRef]

64. Huong-Anh, N.T.; Van Chinh, D.; Tuyet-Hanh, T.T. Antibiotic Residues in Chickens and Farmers' Knowledge of Their Use in Tay Ninh Province, Vietnam, in 2017. Asia Pac. J. Public Health 2020, 32, 126-132. [CrossRef] [PubMed]

65. Rahmatallah, N.; El Rhaffouli, H.; Amine, I.L.; Sekhsokh, Y.; Fihri, O.F.; El Houadfi, M. Consumption of antibacterial molecules in broiler production in Morocco. Vet. Med. Sci. 2018, 4, 80-90. [CrossRef] [PubMed]

66. Sajid, A.; Kashif, N.; Kifayat, N.; Ahmad, S. Detection of antibiotic residues in poultry meat. Pak. J. Pharm. Sci. 2016, 29, 1691-1694. [PubMed]

67. Neogi, S.B.; Islam, M.; Islam, S.S.; Akhter, A.H.M.T.; Sikder, M.H.; Yamasaki, S.; Kabir, S.M.L. Risk of multi-drug resistant Campylobacter spp. and residual antimicrobials at poultry farms and live bird markets in Bangladesh. BMC Infect. Dis. 2020, 20, 1-14. [CrossRef]

68. Lapierre, L.; Quintrel, M.; Lagos-Susaeta, F.; Hervé-Claude, L.P.; Riquelme, R.; Oviedo, P.; Maino, M.; Cornejo, J. Assessment of Antimicrobial and Pesticide Residues in Food Products Sourced from Peasant Family Farming in Chile. J. Food Prot. 2019, 82, 1583-1590. [CrossRef] [PubMed]

69. Doğan, Y.N.; Pamuk, Ş.; Gürler, Z. Chloramphenicol and sulfonamide residues in sea bream (Sparus aurata) and sea bass (Dicentrarchus labrax) fish from aquaculture farm. Environ. Sci. Pollut. Res. 2020, 27, 41248-41252. [CrossRef]

70. Santos, L.; Rosa, J.; Freitas, A.; Leston, S.; Barbosa, J.; Ramos, F. Detection and quantification of 47 antibiotic residues in farmed European sea bass (Dicentrarchus labrax) using a multi-class and multi-residue UHPLC-MS/MS method. Food Addit. Contam. Part A 2019, 36, 561-570. [CrossRef]

71. Gaspar, A.F.; Santos, L.; Rosa, J.; Leston, S.; Barbosa, J.; Pouca, A.S.V.; Freitas, A.; Ramos, F. Development and validation of a multi-residue and multi-class screening method of 44 antibiotics in salmon (Salmo salar) using ultra-highperformance liquid chromatography/time-of-flight mass spectrometry: Application to farmed salmon. J. Chromatogr. B 2019, 1118-1119, 78-84. [CrossRef]

72. Griboff, J.; Carrizo, J.C.; Bonansea, R.I.; Valdés, M.E.; Wunderlin, D.A.; Amé, M.V. Multiantibiotic residues in commercial fish from Argentina. The presence of mixtures of antibiotics in edible fish, a challenge to health risk assessment. Food Chem. 2020, 332, 127380. [CrossRef] [PubMed]

73. Bortolotte, A.R.; Daniel, D.; Braga, P.A.D.C.; Reyes, F.G.R. A simple and high-throughput method for multiresidue and multiclass quantitation of antimicrobials in pangasius (Pangasionodon hypophthalmus) fillet by liquid chromatography coupled with tandem mass spectrometry. J. Chromatogr. B 2019, 1124, 17-25. [CrossRef]

74. Guidi, L.R.; Tette, P.A.S.; Gloria, M.B.A.; Fernandes, C. A simple and rapid LC-MS/MS method for the determination of amphenicols in Nile tilapia. Food Chem. 2018, 262, 235-241. [CrossRef]

75. Serra-Compte, A.; Álvarez-Muñoz, D.; Rodríguez-Mozaz, S.; Barceló, D. Multi-residue method for the determination of antibiotics and some of their metabolites in seafood. Food Chem. Toxicol. 2017, 104, 3-13. [CrossRef]

76. Jansomboon, W.; Boontanon, S.K.; Boontanon, N.; Polprasert, C.; Da, C.T. Monitoring and determination of sulfonamide antibiotics (sulfamethoxydiazine, sulfamethazine, sulfamethoxazole and sulfadiazine) in imported Pangasius catfish products in Thailand using liquid chromatography coupled with tandem mass spectrometry. Food Chem. 2016, 212, 635-640. [CrossRef]

77. Palaniyappan, V.; Nagalingam, A.K.; Ranganathan, H.P.; Kandhikuppam, K.B.; Kothandam, H.P.; Vasu, S. Antibiotics in South Indian coastal sea and farmed prawns (Penaeus monodon). Food Addit. Contam. Part B 2013, 6, 196-199. [CrossRef] [PubMed]

78. Guidi, L.R.; Santos, F.A.; Ribeiro, A.C.S.; Fernandes, C.; Silva, L.H.; Gloria, M.B.A. Quinolones and tetracyclines in aquaculture fish by a simple and rapid LC-MS/MS method. Food Chem. 2018, 245, 1232-1238. [CrossRef] [PubMed]

79. Willis, C.; Booth, H.; Westacott, S.; Hawtin, P. Detection of antibacterial agents in warm water prawns. Commun. Dis. Public Health 1999, 2, 210-214.

80. Abe, N.; Fuchino, K. Survey of Residual Antibiotic Agents in Cultured Fish and Shellfish. J. Food Hyg. Soc. Jpn. 2001, 42, 335-338. [CrossRef]

81. Yen, N.T.P.; Nhung, N.T.; Van, N.T.B.; Van Cuong, N.; Chau, L.T.T.; Trinh, H.N.; Van Tuat, C.; Tu, N.D.; Lan, N.P.H.; Campbell, J.; et al. Antimicrobial residues, non-typhoidal Salmonella, Vibrio spp. and associated microbiological hazards in retail shrimps purchased in Ho Chi Minh city (Vietnam). Food Control. 2020, 107, 106756. [CrossRef]

82. Zhang, R.; Pei, J.; Zhang, R.; Wang, S.; Zeng, W.; Huang, D.; Wang, Y.; Zhang, Y.; Wang, Y.; Yu, K. Occurrence and distribution of antibiotics in mariculture farms, estuaries and the coast of the Beibu Gulf, China: Bioconcentration and diet safety of seafood. Ecotoxicol. Environ. Saf. 2018, 154, 27-35. [CrossRef]

83. Jansomboon, W.; Boontanon, S.K.; Boontanon, N.; Polprasert, C. Determination and health risk assessment of enrofloxacin, flumequine and sulfamethoxazole in imported Pangasius catfish products in Thailand. J. Environ. Sci. Health Part B 2017, 53, 108-115. [CrossRef] [PubMed]

84. Mokh, S.; El Hawari, K.; Rahim, H.A.; Al Iskandarani, M.; Jaber, F. Antimicrobial residues survey by LC-MS in food-producing animals in Lebanon. Food Addit. Contam. Part B 2020, 13, 121-129. [CrossRef] [PubMed] 
85. Mensah, S.E.P.; Koudandé, O.D.; Sanders, P.; Laurentie, M.; Mensah, G.A.; Abiola, F.A. Antimicrobial residues in foods of animal origin in Africa: Public health risks. Rev. Sci. Tech. 2014, 33, 987.

86. Njoga, E.O.; Onunkwo, J.I.; Okoli, C.E.; Ugwuoke, W.I.; Nwanta, J.A.; Chah, K.F. Assessment of antimicrobial drug administration and antimicrobial residues in food animals in Enugu State, Nigeria. Trop. Anim. Health Prod. 2018, 50, 897-902. [CrossRef]

87. Ondieki, G.K.; Ombui, J.N.; Obonyo, M.; Gura, Z.; Githuku, J.; Orinde, A.B.; Gikunju, J.K. Antimicrobial residues and compositional quality of informally marketed raw cow milk, Lamu West Sub-County, Kenya, 2015. Pan. Afr. Med. J. 2017, 28, 5. [CrossRef]

88. Nhung, N.T.; Van, N.T.B.; Van Cuong, N.; Duong, T.T.Q.; Nhat, T.T.; Hang, T.T.T.; Nhi, N.T.H.; Kiet, B.T.; Hien, V.B.; Ngoc, P.T.; et al. Antimicrobial residues and resistance against critically important antimicrobials in non-typhoidal Salmonella from meat sold at wet markets and supermarkets in Vietnam. Int. J. Food Microbiol. 2018, 266, 301-309. [CrossRef]

89. Baghani, A.; Mesdaghinia, A.; Rafieiyan, M.; Dallal, M.M.S.; Douraghi, M. Tetracycline and ciprofloxacin multiresidues in beef and chicken meat samples using indirect competitive ELISA. J. Immunoass. Immunochem. 2019, 40, 328-342. [CrossRef]

90. Yamaguchi, T.; Okihashi, M.; Harada, K.; Konishi, Y.; Uchida, K.; Do, M.H.N.; Bui, H.D.T.; Nguyen, T.D.; Nguyen, P.D.; Van Chau, V.; et al. Antibiotic Residue Monitoring Results for Pork, Chicken, and Beef Samples in Vietnam in 2012-2013. J. Agric. Food Chem. 2015, 63, 5141-5145. [CrossRef]

91. Bahmani, K.; Shahbazi, Y.; Nikousefat, Z. Monitoring and risk assessment of tetracycline residues in foods of animal origin. Food Sci. Biotechnol. 2020, 29, 441-448. [CrossRef]

92. Mitema, E.S.; Kikuvi, G.M.; Wegener, H.C.; Stohr, K. An assessment of antimicrobial consumption in food producing animals in Kenya. J. Vet. Pharmacol. Ther. 2002, 24, 385-390. [CrossRef]

93. Donoghue, D.J. Antibiotic residues in poultry tissues and eggs: Human health concerns? Poult. Sci. 2003, 82, 618-621. [CrossRef]

94. Quintanilla, P.; Doménech, E.; Escriche, I.; Beltrán, M.C.; Molina, M.P. Food Safety Margin Assessment of Antibiotics: Pasteurized Goat's Milk and Fresh Cheese. J. Food Prot. 2019, 82, 1553-1559. [CrossRef]

95. Kühne, M.; Körner, U.; Wenzel, S. Tetracycline residues in meat and bone meals. Part 2: The effect of heat treatments on bound tetracycline residues. Food Addit. Contam. 2001, 18, 593-600. [CrossRef]

96. Gratacós-Cubarsí, M.; Fernandez-García, A.; Picouet, P.; Valero-Pamplona, A.; García-Regueiro, J.-A.; Castellari, M. Formation of Tetracycline Degradation Products in Chicken and Pig Meat under Different Thermal Processing Conditions. J. Agric. Food Chem. 2007, 55, 4610-4616. [CrossRef]

97. Roca, M.; Castillo, M.; Marti, P.; Althaus, R.L.; Molina, M.P. Effect of Heating on the Stability of Quinolones in Milk. J. Agric. Food Chem. 2010, 58, 5427-5431. [CrossRef]

98. Roca, M.; Villegas, L.; Kortabitarte, M.; Althaus, R.; Molina, M. Effect of heat treatments on stability of $\beta$-lactams in milk. J. Dairy Sci. 2011, 94, 1155-1164. [CrossRef]

99. Shakila, R.J.; Vyla, S.A.P.; Kumar, R.S.; Jeyasekaran, G.; Jasmine, G.I. Stability of chloramphenicol residues in shrimp subjected to heat processing treatments. Food Microbiol. 2006, 23, 47-51. [CrossRef] [PubMed]

100. Reyes-Herrera, I.; Schneider, M.J.; Cole, K.; Farnell, M.B.; Blore, P.J.; Donoghue, D.J. Concentrations of Antibiotic Residues Vary between Different Edible Muscle Tissues in Poultry. J. Food Prot. 2005, 68, 2217-2219. [CrossRef] [PubMed]

101. Reyes-Herrera, I.; Donoghue, D.J. Antibiotic Residues Distribute Uniformly in Broiler Chicken Breast Muscle Tissue. J. Food Prot. 2008, 71, 223-225. [CrossRef]

102. Terry, A.L.; Herrick, K.A.; Afful, J.; Ahluwalia, N. Seafood Consumption in the United States, 2013-2016; NCHS Data Brief; U.S. Department of Health \& Human Services: Washington, DC, USA, 2018; pp. 1-8.

103. El Sheikha, A.F.; Montet, D. How to Determine the Geographical Origin of Seafood? Crit. Rev. Food Sci. Nutr. 2013, 56, 306-317. [CrossRef]

104. Denver, S.; Jensen, J.D.; Christensen, T. Consumer preferences for reduced antibiotic use in Danish pig production. Prev. Vet. Med. 2021, 189, 105310. [CrossRef]

105. Gebreyes, W.A.; Bahnson, P.B.; Funk, J.A.; Mckean, J.; Patchanee, P. Seroprevalence of Trichinella, Toxoplasma, and Salmonella in Antimicrobial-Free and Conventional Swine Production Systems. Foodborne Pathog. Dis. 2008, 5, 199-203. [CrossRef]

106. Del Fiol, F.S.; Balcão, V.M.; Barberato-Fillho, S.; Lopes, L.C.; Bergamaschi, C.C. Obesity: A New Adverse Effect of Antibiotics? Front. Pharmacol. 2018, 9. [CrossRef] [PubMed]

107. Riley, L.W.; Raphael, E.M.; Faerstein, E.M. Obesity in the United States-Dysbiosis from Exposure to Low-Dose Antibiotics? Front. Public Health 2013, 1, 69. [CrossRef] [PubMed]

108. Principi, N.; Esposito, S. Antibiotic administration and the development of obesity in children. Int. J. Antimicrob. Agents 2016, 47, 171-177. [CrossRef]

109. Sarkar, A.; Yoo, J.Y.; Dutra, S.V.O.; Morgan, K.H.; Groer, M. The Association between Early-Life Gut Microbiota and Long-Term Health and Diseases. J. Clin. Med. 2021, 10, 459. [CrossRef] 